\title{
Mitogenic Response of Canine Fundic Epithelial Cells in Short-term Culture to Transforming Growth Factor $\alpha$ and Insulinlike Growth Factor I
}

\author{
Monica C. Chen, Alexander T. Lee, and Andrew H. Soll \\ Center for Ulcer Research and Education, and the Medical and Research Services, Veterans Administration Wadsworth Hospital Center, \\ the School of Medicine, University of California at Los Angeles, Los Angeles, California 90073
}

\begin{abstract}
We report methods allowing the culture of rapidly dividing gastric epithelial cells to investigate the regulation of mucosal cell replication. Cells from canine fundic mucosa were dispersed by enzyme treatment, enriched by filtration and elutriation, and cultured on collagen gel in DMEM/F12 medium. After $48 \mathrm{~h}$, $>95 \%$ of the cells displayed immunoreactivity with antibody to cytokeratin, an epithelial marker. The cells formed confluent monolayers by $72 \mathrm{~h}$ with a transmembrane resistance of 1,600 $\mathrm{ohm} \cdot \mathrm{cm}^{2}$ when mounted in a Ussing chamber indicating retention of epithelial cell characteristics. Calf serum (0.1-2\%) produced a dose-dependent mitogenic effect evident by increases in $\left[{ }^{3} \mathbf{H}\right]$-thymidine incorporation into acid-precipitated material and in cell number. After an 18-24-h incubation with $\left.{ }^{3} \mathrm{H}\right]-$ thymidine, $\sim 55 \%$ of the cells cultured in $2 \%$ serum showed evidence of DNA synthesis by autoradiography and all of the replicating cells were cytokeratin positive. Using comparable culture conditions, a similar proportion of cells incubated for 18-24 h with bromodeoxyuridine displayed nuclear anti-bromodeoxyuridine immunoreactivity, thus indicating that over half of the cells in these cultures synthesized DNA during this period. As with serum, epidermal growth factor and transforming growth factor alpha (TGF $\alpha)(10 \mathrm{pM}$ to $1 \mathrm{nM})$, insulin (10 $\mathrm{nM}$ to $1 \mu \mathrm{M}$ ) and insulinlike growth factor-I (IGF-I, 1-100 $\mathrm{nM}$ ) increased $\left[{ }^{3} \mathbf{H}\right]$-thymidine uptake. The greater potency of IGF-I, compared to insulin, suggests the presence of IGF-I receptors. We conclude that this culture preparation is composed of fundic mucosal epithelial cells and contains a predominance of dividing epithelial cells. EGF/TGF $\alpha$ and IGF-I are potential factors directly regulating proliferation of fundic mucosal cells. (J. Clin. Invest. 1991. 87:1716-1723.) Key words: gastric mucosa • cell separation • cell growth • epidermal growth factor $\bullet$ peptic ulcer
\end{abstract}

\section{Introduction}

The gastric mucosa is a rapidly proliferating tissue, being renewed by replicating cells present in a proliferative zone located in the isthmus (neck) of the gastric gland. The migration time of cells from the progenitor zone to the mucosal surface (the time for total replacement of surface epithelial cells) is $\sim 3$ $d$ in the rat and 4-6 d in human and $\operatorname{dog}(1)$. Monitoring $\left[{ }^{3} \mathrm{H}\right]-$

Address correspondence to Andrew H. Soll, M.D., VA Wadsworth Hospital Center, Bldg. 115, Rm. 203, Los Angeles, CA 90073.

Received for publication 25 June 1990 and in revised form 31 October 1990.

The Journal of Clinical Investigation, Inc.

Volume 87, May 1991, 1716-1723 thymidine (THM) ${ }^{1}$ labeling in vivo, mucous neck cells were confirmed to rapidly replenish sloughed surface epithelium, whereas many fewer cells migrated downward into the gastric glands to replace parietal and chief cells. Chief cells may also undergo division at a slow rate, thus appearing to constitute a separate slow-cycling replicating cell pool $(2,3)$. Immature parietal cells, located in the upper part of the gastric glands, also appeared to incorporate thymidine (4), whereas mature parietal cells showed no such evidence of division. Mucous neck cells and immature parietal cells have been hypothesized to be a single cell type in different stages of proliferation, migration, and differentiation (4). Although the replenishment of the gastric and duodenal mucosa is of obvious critical importance to maintaining mucosal integrity in the normal state and in response to injury, knowledge regarding regulation of epithelial cell growth remains limited. In vivo models have been utilized to investigate factors regulating mucosal growth. For example, in the rat, EGF was found to stimulate $\left[{ }^{3} \mathrm{H}\right]-\mathrm{THM}$ incorporation into DNA (5-7) and to increase gastric mucosal weight, thickness, and parietal cell mass (2). Although these findings indicate that EGF has trophic effects on stomach in vivo, the cellular site and mechanism of action remain uncertain.

Several cell culture models have been reported for gastrointestinal mucosal cells. Harvesting cells by mechanical methods has allowed culture of normal human epithelial cells from colon, small intestine, and stomach (8). In these studies cells grew in suspension in clusters, rather than as adherent cells in monolayers. Proliferation was observed in the center of the clusters, and epithelial characteristics (e.g., junctional complexes, staining for cytokeratin) were reported. Conditioned medium induced cell growth, but responses of these cells to specific growth factors were not reported. Fetal rabbit gastric epithelial cells consisting mainly of surface mucous cells (50-60\%) have been observed to proliferate in primary culture and form monolayers within a week (9). However, this model required the addition of $10-20 \%$ calf serum for cell proliferation, and the proliferating cell population was not well characterized. Nontransformed epithelial cell lines have been established from rat intestine (10) and human colon (11). Cultures of well-differentiated transformed cells have been established from human gastric carcinoma (12).

The goal of our present studies is to investigate the regulation of growth in normal gastric mucosa. The available culture models for gastric mucosa do not appear to permit detailed study of the regulation of proliferation by specific growth factors. Furthermore, since alterations in control mechanisms may occur with either transformed or nontransformed cell

1. Abbreviations used in this paper: $\mathrm{BrdU}$, bromo-deoxyuridine; $\mathrm{DAB}$, 3.3'-diaminobenzidine; EGF, epidermal growth factor; IGF-I, insulinlike growth factor; $I_{s c}$, short circuit current; $M R C$, fundic mucosal replicating cells; PDGF, platelet-derived growth factor; $\mathbf{R}_{\mathbf{0}}$, serum-free, growth factor-free medium; TGF $\alpha$, transforming growth factor $\alpha$; THM, thymidine. 
lines in continuous culture, thus limiting extrapolation to normal mucosa, we have chosen to investigate growth regulation in mucosa utilizing primary cultures of normal canine gastric mucosa. Our present methods were adapted from studies with endothelial cells from canine fundic mucosa (13) in which intact capillary fragments were enriched by selective filtration and elutriation. When we placed these preparations in culture, cells bearing the endothelial marker factor VIII-related antigen (13) became undetectable between 24 and $48 \mathrm{~h}$ in culture. However, a rapidly proliferating cell type was present, which displayed epithelial, rather than fibroblastic or endothelial, characteristics. We now report the methods used for this preparation and present data that receptors for EGF/TGF $\alpha$ and IGF-I induce a mitogenic response in gastric mucosal epithelial cells.

\section{Methods}

\section{Dispersion, cell separation, and culture}

The canine fundic mucosa was dispersed with collagenase and EDTA (14), filtered sequentially through coarse (62 threads/inch) and fine (195 threads/inch) nylon mesh. Material retained on the second filter was suspended in HBSS containing $0.1 \mathrm{mg} / \mathrm{ml}$ dithiothreitol and 0.01 $\mathrm{mg} / \mathrm{ml} \mathrm{DNase}$. This cell suspension was elutriated primarily to eliminate bacteria (15). Cells $\left(2-3 \times 10^{8}\right)$ were loaded into a model $\mathrm{J} 5.0$ elutriator rotor (Beckman Instruments, Inc., Fullerton, CA) at a flow rate of $87.5 \mathrm{ml} / \mathrm{min}$ and an $\mathrm{rpm}$ of 2,000 . After a $500-\mathrm{ml}$ wash at a flow rate of $100 \mathrm{ml} / \mathrm{min}$, a fraction was collected at a flow rate of $200 \mathrm{ml} /$ min and an rpm of 1,460 , thus including cells with apparent cell diameters ranging from 15 to $23 \mu \mathrm{m}$. This cell fraction was then suspended in our basic culture medium $\left(R_{0}\right)$, composed of DMEM/Ham's F-12 (Gibco, Grand Island, NY) in a 1:1 mixture, supplemented with 20 $\mathrm{mM}$ Hepes (Calbiochem Corp., La Jolla, CA), $50 \mu \mathrm{g} / \mathrm{ml}$ gentamicin, $100 \mathrm{U} / \mathrm{ml}$ penicillin, and $100 \mu \mathrm{g} / \mathrm{ml}$ streptomycin (Irvine Scientific, Santa Ana, CA). $R_{0}$ refers to medium without added growth factors or serum, which were only added as indicated. Calf serum ( $2 \%$, Gibco) was added to this $R_{0}$ medium for the initial overnight culture in which cells $\left(1.5 \times 10^{5}\right.$ cells in $\left.0.5 \mathrm{ml}\right)$ were plated onto polymerized type I rat tail collagen in 24-well tissue culture plates (Flow Laboratories, McLean, VA) for growth studies, or Lab Tek slides (Nunc Inc., Naperville, IL) for autoradiography and histochemistry. After overnight culture, the standard protocol was to remove this medium, wash the cells twice in fresh $\mathrm{R}_{\mathbf{0}}$ without added GF or serum. Serum, EGF (Amgen Corp., Thousand Oaks, CA), TGF $\alpha$ (Bachem, Inc., Torrance, CA), insulin or IGF-I (Bachem, Inc.) were added for the subsequent culture period, only as indicated. Petri dishes $(35 \mathrm{~mm}$, Corning Glass Works, Corning, NY) were also used for some histochemistry studies.

\section{Transepithelial electrophysiology}

Elutriated epithelial cells $\left(4.0 \times 10^{6}\right.$ cells in $2 \mathrm{ml}$ per $35 \mathrm{~mm}$ petri dish) were plated on collagen-coated filters (type SS, Millipore Corp., Bedford, MA) and cultured in $\mathrm{R}_{0}$ with $2 \%$ calf serum. These cultures formed confluent monolayers after $72 \mathrm{~h}$. These filters were mounted in Ussing chambers and electrophysiological properties of the monolayers studied, as previously described $(15,16)$.

\section{Immunohistochemistry}

Immunohistochemical staining was performed with cells cultured for 24-48 $\mathrm{h}$ after Bouin's fixation using the avidin-biotin-peroxidase complex (ABC) method (17). Immunohistochemistry was performed using monoclonal antibodies to the epithelial cell marker human cytokeratin (AE1/AE3, 1:50, Boehringer Mannheim Biochemicals, Indianapolis, IN) (18), $\mathrm{H}^{+} / \mathrm{K}^{+}$-ATPase (19), and pepsinogen I $(20,21)$. The latter two antibodies were kindly provided respectively by Dr. A. Smolka (Charleston, SC) and Dr. I. M. Samloff (Sepulveda, CA), respectively. Rabbit polyclonal antibodies to factor VIII-related antigen was obtained from Dr. R. Benson (Albany, NY). Second antibodies are biotinylated and visualized with a peroxidase complex and DAB $\left(3,3^{\prime}-\right.$ diaminobenzidine, Sigma Chemical Co., St. Louis, MO) dye. 200 cells in each of five fields were counted on coded slides by two observers unaware of the code.

\section{Measures of cell replication}

Cell number. Cells were detached from the culture wells by treating with trypsin-EDTA (Gibco) for $20 \mathrm{~min}$. Cells were then counted in triplicate in a particle data counter.

Autoradiography of $\left[{ }^{3} \mathrm{H}\right]-\mathrm{THM}$ incorporation. Cells after overnight culture on collagen-coated Lab Tek slides were incubated with $\left[{ }^{3} \mathrm{H}\right]-$ THM $(2 \mu \mathrm{Ci} / \mathrm{ml}$, New England Nuclear, Boston, MA) for 18-24 h. Cells were washed and fixed with Bouin's solution. Slides were dipped with emulsion (type NTB2, Eastman Kodak Co., Rochester, NY) and exposed for 2-3 wk at $4^{\circ} \mathrm{C}$. Slides were then developed in Kodak D-19 and counterstained with hematoxylin.

BrdU incorporation. DNA synthesis was measured by determining the nuclear uptake of the thymidine analogue BrdU (Sigma Chemical Co.). After overnight culture, cells were treated with $10 \mu \mathrm{M}$ BrdU for an additional $18 \mathrm{~h}$, washed, and fixed with ethanol. Immunofluorescence was performed using a monoclonal antibody to BrdU (Becton Dickinson \& Co., Salt Lake City, UT), with a FITC-conjugated second antibody.

Cell mass. Cell mass was determined by measuring $\beta$-hexosaminidase, a lysosomal enzyme. Cells were incubated with exogenous substrate ( $P$-nitrophenyl- $N$-acetyl-B-D-glucosaminide) (Sigma Chemical Co.) at $37^{\circ} \mathrm{C}$ for $30 \mathrm{~min}$. The reaction was stopped by adding glycine/ EDTA ( $\mathrm{pH} \mathrm{10).} \mathrm{The} \mathrm{resulting} \mathrm{product} \mathrm{in} \mathrm{the} \mathrm{media} \mathrm{was} \mathrm{spectrophoto-}$ metrically determined (OD at $405 \mathrm{~nm}$ ) (22).

$\left[{ }^{3} H\right]-T H M$ incorporation. Epithelial cells were plated onto 24-well plates in $\mathrm{R}_{0}$ with $2.0 \%$ calf serum for overnight culture. Cells were then washed and incubated for an additional $24 \mathrm{~h}$ in fresh $\mathrm{R}_{0}$ medium in the presence of $\left[{ }^{3} \mathrm{H}\right]-\mathrm{THM}(0.5 \mu \mathrm{Ci} / \mathrm{ml})$, with EGF, TGF $\alpha$, insulin, IGF-I, or serum added as indicated. Cells were washed in PBS, $10 \%$ TCA $\left(4^{\circ} \mathrm{C}\right)$ was added and replaced for two 10 -min periods. The material precipitated in TCA was solubilized in $\mathrm{NaOH}$ and radioactivity counted in a model 7500 liquid scintillation counter (Beckman Instruments, Inc.). For some studies, as indicated in the legends, we have inserted an 8-12-h additional incubation period in $R_{0}$ before growth factor and $\left[{ }^{3} \mathrm{H}\right]$-THM was added.

\section{Combined autoradiography and immunohistochemistry}

Cells cultured in Lab Tek slide chambers were incubated in $\left[{ }^{3} \mathrm{H}\right]-\mathrm{THM}$ as noted above for the autoradiography studies. After fixation in Bouin's, immunohistochemistry using the $A B C$ method was performed to demonstrate cytokeratin. Autoradiography for $\left[{ }^{3} \mathrm{H}\right]-\mathrm{THM}$ was then completed, as noted above.

\section{Results}

\section{Cell separation, culture, and identification}

Methods for preparing fundic replicating cells were developed from those used for mucosal endothelial cells (13) in which the crude enzyme-dispersed cell preparation was filtered. For culture studies the mixed population of single cells and gastric glands, and capillary fragments retained on nylon mesh was elutriated. After elutriation, this preparation was characterized by examining slides prepared by cytocentrifugation, stained with periodic acid Schiff (PAS) reagent (23) or stained by immunohistochemistry. At the time of plating, of the cells examined, $19 \pm 6 \%$ of the cells reacted with antibodies to $\mathrm{H}^{+} / \mathrm{K}^{+}$-ATPase, and $40 \pm 8 \%$ contained pepsinogen I-like immunoreactivity. On PAS staining, $23 \pm 6 \%$ contained positive granules typical of mucous cells. Capillary fragments were also found in these cytospins, and $22 \pm 7 \%$ of the cells reacted with antibodies to factor VIII-related antigen (mean $\pm \mathrm{SE}, n=3$ ) (Table I). These preparations were cultured in $2 \%$ calf serum in Lab Tek 
Table I. Cellular Composition of Cultured Fundic Mucosal Epithelial Cells

\begin{tabular}{ccccc}
\hline Time of culture & $\begin{array}{c}\text { Pepsinogen } \\
(n=4)\end{array}$ & $\begin{array}{c}\mathrm{H}^{+} / \mathrm{K}^{+} \\
\text {ATPase } \\
(n=4)\end{array}$ & $\begin{array}{c}\text { PAS } \\
(n=3)\end{array}$ & $\begin{array}{c}\text { Factor VIII- } \\
\text { related Ag } \\
(n=3)\end{array}$ \\
\hline$h$ & $\%$ & $\%$ & $\%$ & $\%$ \\
0 & $40 \pm 8$ & $19 \pm 6$ & $23 \pm 6$ & $22 \pm 7$ \\
24 & $45 \pm 9$ & $20 \pm 6$ & - & $15 \pm 7$ \\
48 & $39 \pm 11$ & $20 \pm 7$ & - & $<1$ \\
\hline
\end{tabular}

At the time of plating $(T=0)$, cytospins were used for immunohistochemistry. At $T=24$ or $48 \mathrm{~h}$, cultured cells on Lab Tek slides were used for immunohistochemistry. Results, the mean $\pm \mathrm{SE}$, are expressed as the percentage of the total cell population. The ABC method was used for all antibodies, except that immunofluorescent was used for factor VIII-related antigen (Ag).

slide chambers, and then the cellular composition was examined by immunohistochemistry after 24 and $48 \mathrm{~h}$ (Table I). At these two time points, $45 \pm 9 \%$ and $39 \pm 11 \%$ of cells displayed immunoreactivity with pepsinogen $I$, and $20 \pm 6 \%$ and $20 \pm 7 \%$ were reactive with the $\mathrm{H}^{+} / \mathrm{K}^{+}$-ATPase antibody. The PAS stain did not release typical positive granules in the cultured cells, so this marker was not quantitated. These methods did not prove useful for culturing endothelial cells, which was our initial goal; the proportion of cells reactive with antibody to VIII-related antigen decreased to $15 \pm 7 \%$ at $24 \mathrm{~h}$ and $<1 \%$ at $48 \mathrm{~h}$ (Table I). However, these cultures prepared by these methods did contain a rapidly replicating cell population, which we have found to be of epithelial origin.

\section{Epithelial nature of the cells}

Several findings established the epithelial nature of the rapidly dividing cells in these cultures. Phase contrast microscopy of cultures after 24,48 , and $72 \mathrm{~h}$ (Fig. 1) indicated that the cells adherent to the culture substrate had the characteristic cuboidal morphology of epithelial cells. Furthermore, confluent monolayers formed by $\sim 72 \mathrm{~h}$ (Fig. 1). The polarized, epithelial nature of monolayers was demonstrated using electrophysiological methods $(15,16)$ (Fig. 2). Monolayers formed on filters and mounted in Ussing chambers had a "transepithelial" resistance of $1,600 \pm 450 \mathrm{ohm} \cdot \mathrm{cm}^{2}($ mean $\pm \mathrm{SE}, n=6)$; this high resistance could only occur with the formation of tight junctions between the cells of the monolayer. When the membrane was treated on the basolateral surface with 8-bromo-cAMP (0.1 $\mathrm{mM}$ ), the short circuit current increased from 1.2 to $5.4 \mu \mathrm{A}$, indicating the vectorial transport that is characteristic of polarized epithelia.

The presence of cytokeratin fibers provides a specific marker for epithelial cells; immunohistochemistry was used to detect cytokeratin (18). After $48 \mathrm{~h}$ in culture, $95 \pm 5 \%$ (mean $\pm \mathrm{SE}, n=4$ ) of the cells examined stained positively using a cytokeratin antibody (Fig. 3, as shown in cytoplasmic pigment). Furthermore, by combining autoradiography to detect the cells that had incorporated $\left[{ }^{3} \mathrm{H}\right]-$ THM into DNA with immunohistochemistry for cytokeratin, we found that essentially all of the cells that had synthesized DNA in culture (identified by grains over their nuclei) were cytokeratin-positive (Fig. 3). We conclude that the formation of monolayers with high resistance and polarized transport and the presence of specific markers establishes the epithelial nature of the replicat- ing cells in these cultures. We thus refer to the replicating epithelial cells in these preparations as fundic mucosal replicating cells (MRC).

\section{Assessment of cell replication in culture}

Cell number. Replication of cells in these cultures was studied by counting the number of cells adherent to the plates using phase contrast microscopy (Fig. 1) and by removing cells from the plates using EDTA/trypsin treatment and counting with a Particle Data Counter (Fig. $4 \mathrm{~A}$ ). With both of these techniques, the number of cells cultured in the presence of $2 \%$ calf serum increased over $72 \mathrm{~h}$ in culture, indicating the occurrence of cell replication in these cultures.

$\left[{ }^{3} \mathrm{H}\right]-T H M$ and bromodeoxyuridine incorporation into DNA. DNA synthesis was demonstrated by incubating cells with $2 \mu \mathrm{Ci} / \mathrm{ml}\left[{ }^{3} \mathrm{H}\right]-\mathrm{THM}$, followed by autoradiography to identify and quantify the replicating cells present in these cultures. With an 18-24-h exposure to [ $\left.{ }^{3} \mathrm{H}\right]-\mathrm{THM}$, we found that $55 \pm 9 \%($ mean $\pm \mathrm{SE} ; n=5)$ of the cells present displayed radioactivity localized over nuclei (Fig. 3). DNA synthesis was also demonstrated by incubating cells with bromodeoxyuridine (BrdU), an analogue of thymidine which is incorporated into newly synthesized DNA (24). BrdU-labeled cells were detected using immunofluorescence with a monoclonal antibody to BrdU. Following exposure of cells after overnight culture to 10 $\mu \mathrm{M}$ BrdU for $3 \mathrm{~h}, 5-10 \%$ of the cells were labeled. When the exposure time was increased to $18 \mathrm{~h}, 47 \pm 8 \%($ mean $\pm \mathrm{SE}, n=4)$ of the cells has entered $\mathrm{S}$ phase, as evident by BrdU-labeled nuclei. This value was similar to that found in the studies using autoradiography.

Quantification of cell replication. Quantitative studies of cell replication used cell number, the activity of hexosaminidase, a lysosomal enzyme marker of cell mass, and the incorporation of $\left[{ }^{3} \mathrm{H}\right]-\mathrm{THM}$ into DNA, detected as TCA-precipitated radioactivity.

\section{Stimulation of proliferation}

Mitogenic response to serum. Central to this study is the response of epithelial replicating cells to mitogenic stimuli. Calf serum induced a dose-dependent increase in cell number, cell mass, and $\left[{ }^{3} \mathrm{H}\right]$-THM incorporation (Fig. 4, $A$ and $B$ ). These patterns of response were similar; we found $\left[{ }^{3} \mathrm{H}\right]$-THM incorporation to be useful as our routine measure of cell proliferation. The maximal response to serum, generally a twofold increase over basal, was observed at serum concentrations between 0.5 and $2.5 \%$. A significant mitogenic effect was found at a serum concentration of $0.1 \%$, indicating a sensitive growth response of these cells to serum. Dog serum, collected from a single animal and heat-inactivated $\left(30 \mathrm{~min}, 56^{\circ} \mathrm{C}\right)$, also produced similar stimulation on growth (data not illustrated). Even in serum-free conditions ( $\bullet$ in Fig. $4 \mathrm{~B}$ ), cells remained viable and incorporated $\left[{ }^{3} \mathrm{H}\right]-\mathrm{THM}$ at a slow but definite rate.

Mitogenic response to EGF and TGF $\alpha$. Human EGF at doses between $1 \mathrm{pM}$ and $1 \mathrm{nM}$ produced a dose-dependent increase in $\left[{ }^{3} \mathrm{H}\right]-\mathrm{THM}$ incorporation into acid-precipitated material (Fig. $5 \mathrm{~A}$ ); these studies were done with the cells incubated in the serum-free $R_{0}$ medium. EGF produced a similar dose response curve against a background of $0.2 \%$ calf serum; the response was additive with serum and of a similar magnitude to that found in serum-free conditions (data not illustrated). Transforming growth factor alpha (TGF $\alpha$ ), a structurally related peptide that acts in part or totally through receptors 

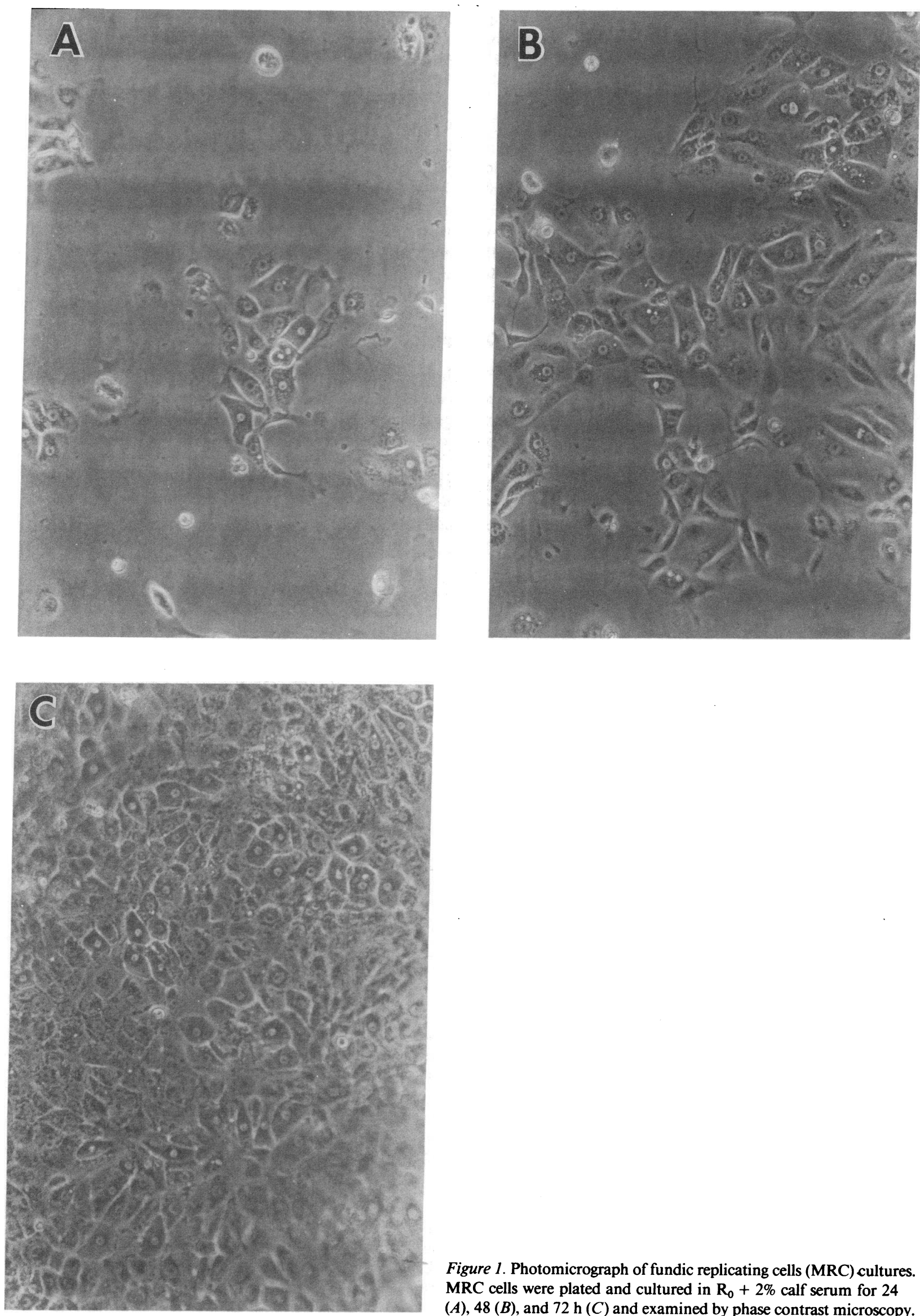

Figure 1. Photomicrograph of fundic replicating cells (MRC) cultures. MRC cells were plated and cultured in $\mathrm{R}_{0}+2 \%$ calf serum for 24 $(A), 48(B)$, and $72 \mathrm{~h}(C)$ and examined by phase contrast microscopy. 


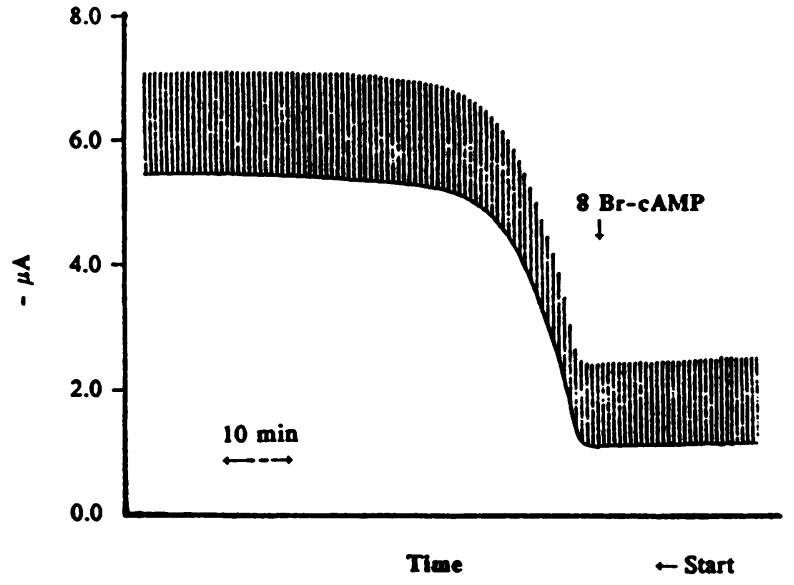

Figure 2. Polarized "transepithelial" function of MRC monolayers. MRC were cultured in $R_{0}+2 \%$ calf serum on collagen-coated Millipore filters until a confluent monolayer had formed $(72 \mathrm{~h})$. Monolayers were mounted in Ussing chambers and electrophysiological properties studied. The solid line depicts the $I_{s c}$ (short circuit current in microamperes). Conductance is depicted by the length of the deflection during a 5- $\mu \mathrm{A}$ pulse. From these data resistance was calculated to be $1,500 \mathrm{ohm} \cdot \mathrm{cm}^{2}$. This tracing illustrates an increase in $I_{s c}$ after basolateral treatment with $0.1 \mathrm{mM}$ 8-bromo cyclic AMP. These data are from a single monolayer and are representative of five other preparations. shared with EGF, stimulated $\left[{ }^{3} \mathrm{H}\right]-\mathrm{THM}$ incorporation by these epithelial cells over a concentration range similar to EGF (Fig. $5 \mathrm{~B}$ ). The magnitude of response to these two peptides was also similar.

Mitogenic response to insulin and IGF-I. Insulin and IGF-I also increased $\left[{ }^{3} \mathrm{H}\right]-\mathrm{THM}$ incorporation into DNA by these epithelial cultures under serum-free conditions (Fig. 6). The dose response for insulin was found at concentrations between $10 \mathrm{nM}$ and $1 \mu \mathrm{M}$, whereas IGF-I produced mitogenic effects at concentrations between 0.1 and $100 \mathrm{nM}$. The response to IGFI was also tested against a background of $0.2 \%$ serum (data not illustrated), with the magnitude of the response and concentration range similar to those observed under the serum-free conditions illustrated in Fig. 6.

\section{Discussion}

Establishing culture methods for replicating normal epithelial cells has proved challenging, in part because "epithelial" cell cultures are often overgrown by fibroblasts, precluding interpretation of data regarding epithelial cell replication. Several lines of evidence indicate that cultures prepared by our present methods after $24 \mathrm{~h}$ consist largely, if not exclusively, of epithelial cells. The great majority of cells display immunoreactivity with antibody to cytokeratin, which is a specific marker of epithelial cells (18). Monolayers form by $72 \mathrm{~h}$ and display the

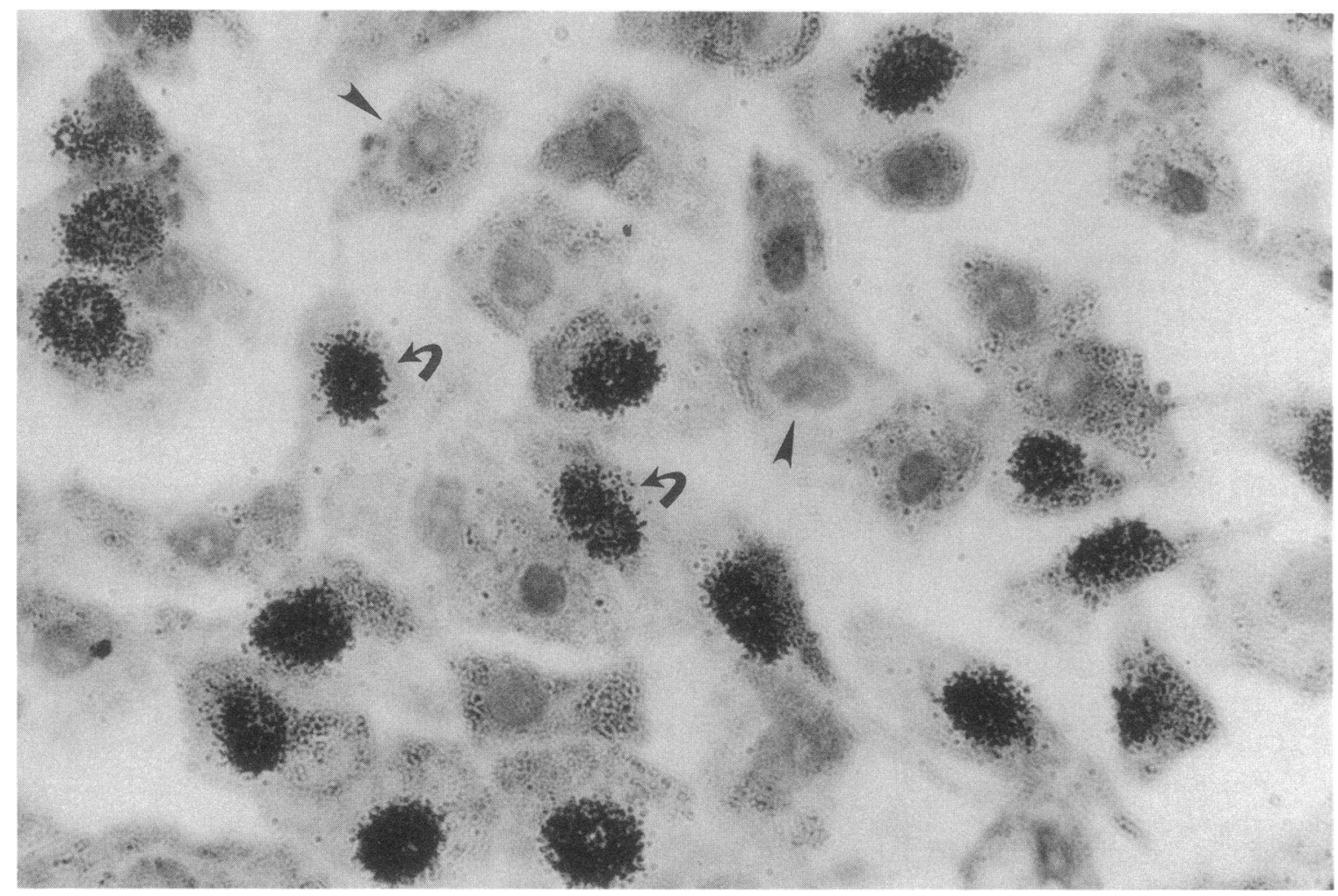

Figure 3. Cytokeratin in cultured gastric epithelial replicating cells. After overnight culture of MRC as outlined in the legend to Fig. 1, cells were washed and incubated with $\mathrm{R}_{0}+2 \% \mathrm{CS}$ with $2 \mu \mathrm{Ci} / \mathrm{ml}\left[{ }^{3} \mathrm{H}\right]-\mathrm{THM}$ for an additional $24 \mathrm{~h}$. Cultures were then washed with PBS and fixed in Bouin's. ABC staining with antibodies AE1/AE3 to cytokeratin was performed and followed by autoradiography. Slides were exposed for 3 wk before developing. Nuclei were counterstained by hematoxylin. Nuclei of cells that had synthesized DNA are peppered with grains (arrow), whereas nuclei of nonreplicating cells demonstrate only background radioactivity (arrowhead). 

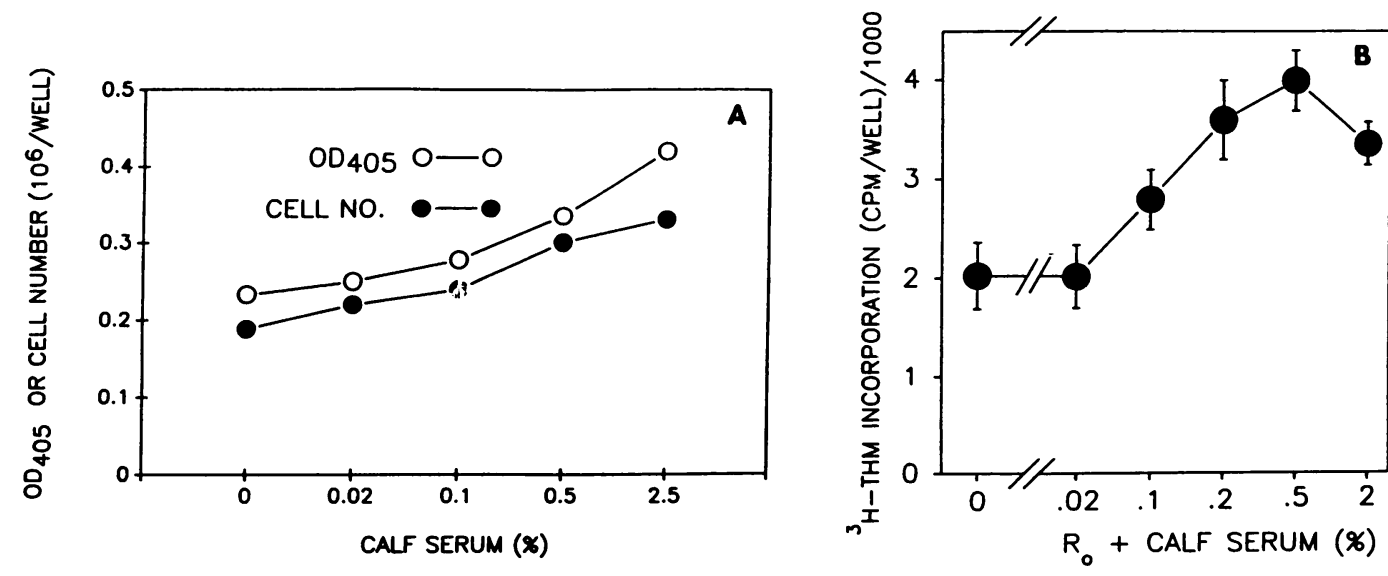

Figure 4. Serum effects on cell growth. Cells were cultured in $R_{0}$ with $2.0 \%$ calf serum overnight. The medium was then changed to the indicated concentrations of calf serum for another $72 \mathrm{~h}$. $(A)$ Cell growth was assessed by cell number, expressed as $10^{6}$ cells per well, and cell mass, measured by hexosaminidase activity, expressed as the $O D$ reading at $405 \mathrm{~nm}$. $(B)$ Cell growth was also determined by $\left[{ }^{3} \mathrm{H}\right]-\mathrm{THM}$ incorporation. Cells were

cultured overnight, washed once, incubated in $R_{0}$ for $8 \mathrm{~h}$ and then placed in fresh $\mathrm{R}_{0}$ in the absence and presence of the indicated concentrations of calf serum and $\left.0.5 \mu \mathrm{Ci} / \mathrm{ml} \mathrm{[}{ }^{3} \mathrm{H}\right]-\mathrm{THM}$ for $24 \mathrm{~h}$. Cultures were washed with PBS and precipitated with $10 \%$ TCA. Acid precipitated counts were then solubilized in $\mathrm{NaOH}$ and counted. Data represent the mean $\pm \mathrm{SE}$ from four preparations and are expressed as radioactivity per well. Statistical significance was assessed using a paired $t$ test.

electrophysiologic properties of a "tight" epithelium, with the mean resistance across these monolayers $1,600 \mathrm{ohm} \cdot \mathrm{cm}^{2}$. Polarized transport is established by finding a short circuit current response to stimulation by a cyclic AMP analogue; this $I_{s c}$ is probably accounted for by absorption of $\mathrm{Na}^{+}$or secretion of $\mathrm{Cl}^{-}(15)$. Finding these characteristic features of a "tight epithelium" precludes the inclusion of nonepithelial cells in these monolayer cultures. Furthermore, using either autoradiography with cells incubated with $\left[{ }^{3} \mathrm{H}\right]-\mathrm{THM}$ or immunohistochemistry after incubation with the thymidine analogue BrdU, over half of the cells cultured in $2 \%$ serum synthesized DNA during an 18-24 h period. Coupling autoradiography for $\left[{ }^{3} \mathrm{H}\right]-$ THM with immunohistochemistry for cytokeratin we found that the cells replicating in these cultures contained this epithelial marker. We therefore conclude that these cultures are composed of epithelial cells bound by tight junctions and that replicating epithelial cells are a predominant cellular component of these cultures.

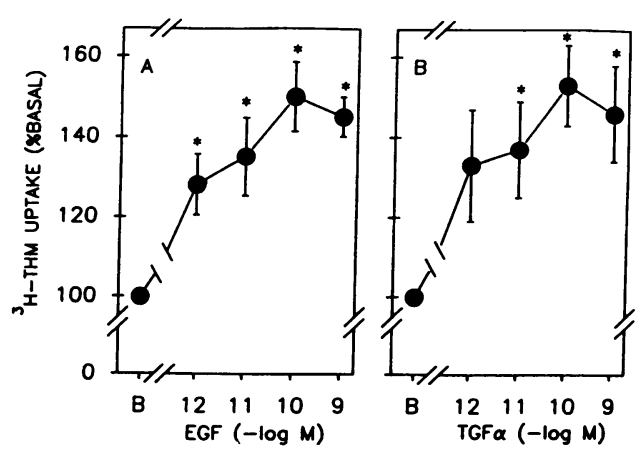

Figure 5. Growth response of cultured MRC to human EGF and TGF $\alpha$. Cells were initially cultured as described in Fig. $4 B$, and then placed in $\mathrm{R}_{0}$ with the indicated concentrations of $\operatorname{EGF}(A)$ and TGF $\alpha$ $(B)$. Cell growth was determined using $\left[{ }^{3} \mathrm{H}\right]-\mathrm{THM}$ incorporation. Data represent the mean $\pm S E$ from four preparations and are expressed as the percentage of basal $\left[{ }^{3} \mathrm{H}\right]-\mathrm{THM}$ uptake. Statistical significance was assessed using a paired $t$ test. ${ }^{*} P<0.05$ vs. basal.
Four indices were used to quantify cell replication, each indicating a steady increase in the number of cells over a 72-h period. (a) Phase contrast photomicrographs indicated cell replication, evident by an increase in the number of adherent cells. The number of adherent cells could increase without cell replication if delayed adherence of cells floating in the culture medium occurs; therefore, floating cells were removed after the initial overnight culture and before the start of these quantitative studies. $(b)$ Counts of cells released from cultures by trypsin and calcium chelation confirmed an increase in cell number over time. (c) A hexosaminidase assay, which reflects cell mass, also indicated cell growth. However, use of this measure is limited by the dissociation that occurs between cell mass and cell number when confluence is approached. $(d)$ These cultures incorporated $\left[{ }^{3} \mathrm{H}\right]-\mathrm{THM}$ into acid-precipitated material, which proved to be the most useful index of mitogenic response. Using these four measures, serum was found to induce proliferation of the fundic epithelial cells in these cultures. Although

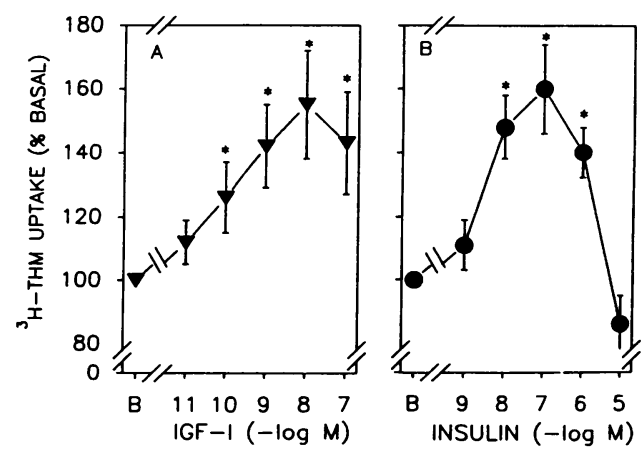

Figure 6. Growth response of cultured MRC to IGF-I and insulin. Cells were initially cultured as described in Fig. $4 \mathrm{~B}$, after 8-12 h culturing in $\mathrm{R}_{0}$, cells were then placed in $\mathrm{R}_{0}$ with the indicated concentrations of IGF-I $(A)$ and insulin $(B)$. Cell growth was determined using $\left[{ }^{3} \mathrm{H}\right]$-THM uptake with treatment for $24 \mathrm{~h}$. Data represent the mean $\pm \mathrm{SE}$ from four preparations and are expressed as percentage of basal $\left[{ }^{3} \mathrm{H}\right]$-THM uptake. Statistical significance was assessed using a paired $t$ test. ${ }^{*} P<0.05$ vs. basal. 
$>50 \%$ of cultured epithelial cells were found to synthesize DNA during 48-72 h, our culture preparation was not homogeneous. This replicating cell population needs to be further characterized to determine whether these cells display markers of mucosal cell differentiation (e.g., pepsinogen $\mathrm{I}, \mathrm{H}^{+} / \mathrm{K}^{+}$-ATPase, or mucin) at the time of division or subsequently express these markers in culture. Such studies are complex and require autoradiography coupled with immunohistochemistry.

Because our goal was to investigate the mechanisms regulating cell growth in the normal gastric mucosa, we sought to develop a primary culture system in which proliferative responses could be characterized within $72 \mathrm{~h}$ of removal from the intact tissue. Although some alteration in cell responses may occur upon dispersion or within hours of culture, our observations with this primary culture system will not be influenced by the alterations in cell characteristics that occur in transformed or nontransformed cell lines in prolonged culture. The doubling time of our fundic mucosal replicating cells in culture with serum is $\sim 48-72 \mathrm{~h}$, depending on culture conditions, and this compares favorably with estimates of 4-6 d in intact dog tissue (1). Thus, these fundic mucosal epithelial cells appear to replicate in culture at a rate roughly comparable to that found in vivo, suggesting that this system may serve as a good model for studying growth regulation of normal gastric mucosa.

Although the addition of serum is required for survival of many culture systems, its presence may perturb epithelial cell function and differentiation (25). Furthermore, we found that serum in concentrations as low as $0.1 \%$ induces proliferation of canine fundic epithelial cells, and its presence may thus confound interpretation of mitogenic responses to specific growth factors. However, fundic epithelial cells cultured by the present methods tolerate serum-free conditions and respond to at least two growth factors under these conditions. The initial adherence of cells was facilitated by adding $2 \%$ serum for the first 12 $h$ of culture. However, after this initial period, serum could be removed without obvious deleterious effects on mitogenic responses. For some of present studies, we have inserted an 8-12$\mathrm{h}$ wash step in serum-free and growth factor-free medium after the initial culture period to allow effects of residual serum to dissipate.

Cell growth is a highly regulated process; polypeptide growth factors acting on surface receptors are major modulating elements for growth control in proliferating epithelial and mesenchymal cells (26). EGF was the first growth factor acting in this fashion to be identified. EGF is synthesized in highest quantities by salivary glands, and it is also found in Bruenners glands from duodenum. EGF is therefore present in saliva and gastric juice, as well as serum. Luminal EGF has been reported to exert a mitogenic effect on gastric mucosa, but the physiologic importance of both luminal and circulating EGF remains uncertain. The study of EGF is further complicated by the existence of TGF $\alpha$. TGF $\alpha$ also exerts a mitogenic effect in a variety of epithelial and mesenchymal tissues and in tumor cells. In contrast to EGF, which appears to be synthesized only in a few specific sites, TGF $\alpha$ is produced by many normal tissues, as well as by tumor cells $(27,28)$. TGF $\alpha$ message has been expressed in many tissues and cells, including the gastrointestinal tract (29), keratinocytes (28), and isolated rat intestinal cells (30). In canine gastric mucosa TGF $\alpha$ message appeared to be present in exocrine cells (31); however, a specific cellular localization was not established. Although the function of TGF $\alpha$ produced in normal tissues has not been established, our data are consistent with the hypothesis that this peptide exerts autocrine and/or paracrine growth control on fundic epithelial cells.

IGF-I, a peptide previously known as somatomedin C, mediates peripheral actions of growth hormone and is a potent mitogen in normal and neoplastic cells $(32,33)$. Many tissues and cell types produce IGF-I, including the adult gastrointestinal tract. In the intact rat, growth hormone induces growth of the fundic mucosa (2), although a specific role of IGF-I in regulating mucosal growth has not been elucidated. In our present study, we found that IGF-I and insulin stimulated $\left[{ }^{3} \mathrm{H}\right]-\mathrm{THM}$ incorporation by fundic epithelial cells. The greater potency of IGF-I compared to insulin suggests mediation by IGF-I receptors. Our data support the conclusion that IGF-I is a direct modulator of fundic epithelial cell growth, and are consistent with the hypothesis that IGF-I is an paracrine or autocrine mediator of gastrointestinal mucosal cell growth (32).

The ability of serum to promote cell growth in vitro probably reflects the presence of one or more specific factors, candidates include transferrin $(34,35)$, fibroblast growth factor (36), IGF-I and factors derived from platelets $(37,38)$. We found that the maximal responses to IGF-I and to EGF were additive with serum, possibly indicating that the effects of serum are not accounted for solely by either of these growth factors. Our present data only indicate that factors in serum potently induce mitogenesis in fundic mucosa; the identity and potential physiologic importance of the putative growth factors in serum remain to be established.

The present studies use a reductionist approach to study the regulation of growth in the fundic mucosa. This regulation is likely to be a complex process; in vivo hormonal mediators (gastrin) $(2,39)$ and neural pathways $(40-42)$ stimulate fundic mucosal growth. Our present data support the hypothesis that TGF $\alpha$ and IGF-I, presumably acting by autocrine and/or paracrine mechanisms, also modulate growth in fundic mucosa. Other paracrine modulators could also be delivered from endothelial cells, fibroblasts, or macrophages. The presence of these numerous potential pathways and interactions complicates study of growth regulation in vivo, because these endogenous regulating factors may mask or interact with exogenous agents. Although such a reductionist system has the potential of defining the components of this complex regulation, there are several limitations. Although $>50 \%$ of the cells in these cultures are capable of dividing within a $24-\mathrm{h}$ period, the cultures contain a heterogeneous cell population. The demonstration of a mitogenic response does not guarantee that the action is directly on the replicating cell. For example, our present data do not exclude the possibility that TGF $\alpha$ or IGF-I exert their growth stimulation via effects on neighboring cells mediated by release of a paracrine growth modulator. Further studies will be needed to localize EGF, TGF $\alpha$, and IGF-I receptors to the replicating cells. Secondly, replicating epithelial cells may not represent a single population, but may include true stem cells (undifferentiated and uncommitted), as well as precursors which may be committed to and possibly express differentiation markers of a specific mucosal cell type. Lastly, although in vitro systems offer the potential of identifying specific cellular mechanisms exerting growth control, findings need to be related back to an intact, integrated system to determine which of 
the candidate mechanisms are operative controlling growth under normal physiologic conditions or accelerating growth in response to acute injury or in response to chronic peptic ulceration.

\section{Acknowledgments}

The authors thank Dr. Martin Martin for discussions about these experiments and Deborah Avedian and Mary Tanner for their indispensable technical support. The authors also thank our collaborators, in particular Drs. Amram Ayalon, Marty Sanders, and Calvin Olson who helped in the development of methods for culturing mucosal cells. We also thank Drs. Catia Sternini, Nick Brecha, Che-Nan Chuang, and Karl Anderson for their ongoing help refining our skills in immunohistochemistry and autoradiography.

Supported by grants from the NIADDK AM 30444 and by the Medical Research Service of the Veterans Administration. Andrew Soll is a recipient of a Medical Investigatorship, VA Wadsworth Hospital Center.

\section{References}

1. Hansen, H. O., T. Pedersen, and J. K. Larsen. 1976. Proliferation kinetics in the normal gastric mucosa. Gastroenterology. 70:1051-1054.

2. Johnson, L. R. 1987. Regulation of gastrointestinal growth. In Physiology of the Gastrointestinal Tract. L. R. Johnson, editor. Raven Press, New York. 301-333.

3. Yeomans, N. D., and J. S. Trier. 1976. Epithelial cell proliferation and migration in the developing rat gastric mucosa. Dev. Biol. 53:206-216.

4. Chen, K. Y., and H. R. Withers. 1975. Proliferative capability of parietal and zymogen cells. J. Anat. 120:421-432.

5. Scheving, L. A., Y. C. Yeh, T. H. Tsai, and L. E. Scheving. 1979. Circadian phase-dependent stimulatory effects of epidermal growth factor on deoxyribonucleic acid synthesis in the tongue, esophagus, and stomach of the adult male mouse. Endocrinology. 105:1475-1480.

6. Feldman, M., J. H. Walsh, H. C. Wong, and C. T. Richardson. 1978. Role of gastrin heptadecapeptide in the acid secretory response to amino acids in man. J. Clin. Invest. 61:308-313.

7. Johnson, L. R., and P. D. Guthrie. 1980. Stimulation of rat fundic gland mucosal growth by epidermal growth factor. Am. J. Physiol. 238:G45-G49.

8. Moyer, M. P. 1983. Culture of human gastrointestinal epithelial cells. Proc. Soc. Exp. Biol. Med. 174:12-15.

9. Matuoka, K. M. Tanaka, Y. Mitsui, and S. Murota. 1983. Cultured rabbit gastric epithelial cells producing prostaglandin $\mathrm{I}_{2}$. Gastroenterology. 84:498-505.

10. Kurokowa, M., K. Lynch, and D. K. Podolsky. 1987. Effects of growth factors on an intestinal epithelial cell line: transforming growth factor beta inhibits proliferation and stimulates differentiation. Biochem. Biophys. Res. Commun. 142:775-782.

11. Chopra, D. P., K. M. Siddiqui, and R. A. Cooney. 1987. Effects of insulin, transferrin, cholera toxin, and epidermal growth factor on growth and morphology of human fetal normal colon epithelial cells. Gastroenterology. 92:891-904.

12. Romano, M., M. Razandi, S. Sekhon, W. J. Krause, and K. J. Ivey. 1988. Human cell line for study of damage to gastric epithelial cells in vitro. $J$. Lab. Clin. Med. 111:430-440.

13. Chen, M. C., M. J. Sanders, D. A. Amirian, L. P. Thomas, G. Kauffman, and A. H. Soll. 1989. Prostaglandin E2 production by dispersed canine fundic mucosal cells. Contribution of macrophages and endothelial cells as major sources. J. Clin. Invest. 84:1536-1549.

14. Soll, A. H. 1978. The actions of secretagogues on oxygen uptake by isolated mammalian parietal cells. J. Clin. Invest. 61:370-380.

15. Ayalon, A., M. J. Sanders, L. P. Thomas, D. A. Amirian, and A. H. Soll 1982. Electrical effects of histamine on monolayers formed in culture from enriched canine gastric chief cells. Proc. Natl. Acad. Sci. USA. 79:7009-7013.

16. Sanders, M. J., A. Ayalon, M. Roll, and A. H. Soll. 1985. The apica surface of canine chief cell monolayers resists $\mathrm{H}+$ back-diffusion. Nature (Lond.). 313:52-54.

17. Hsu, S.-M., L. Raine, and H. Fanger. 1981. Use of avidin-biotin-peroxidase complex $(\mathrm{ABC})$ in immunoperoxidase techniques: a comparison between ABC and unlabeled antibody (PAP) procedures. J. Histochem. Cytochem. 29:577-580.

18. Sun, T. T., and H. Green. 1978. Immunofluorescent staining of keratin fibers in cultured cells. Cell. 14:469-476.
19. Smolka A., H. F. Helander, and G. Sachs. 1983. Monoclonal antibodies against gastric $\mathrm{H}^{+}+\mathrm{K}^{+}$ATPase. 1983. Am. J. Physiol. 245:G589-G596.

20. Shiraishi, T., I. M. Samloff, R. T. Taggart, and G. N. Stemmermann. 1988. Slow moving proteinase in gastric cancer and its relationship to pepsinogen I and II. Dig. Dis. Sci. 33:1466-1472.

21. Stemmermann, G. N., I. M. Samloff, and T. Hayashi. 1985. Pepsinogen I and II in carcinoma of the stomach: an immunohistochemical study. Appl. Pathol. 3:159-163.

22. Landegren, U. 1984. Measurement of cell number by means of the endogenous enzyme hexosaminidase. Applications to detection of lymphokines and cell surface antigens. J. Immunol. Methods. 67:379-388.

23. Soll, A. H., D. A. Amirian, L. P. Thomas, T. J. Reedy, and J. D. Elashoff 1984. Gastrin receptors on isolated canine parietal cells. J. Clin. Invest. 73:1434 1447.

24. Gratzner, H. G. 1982. Monoclonal antibody to 5-bromo- and 5-iododeoxyuridine: a new reagent for detection of DNA replication. Science (Wash. DC). 218:474-475.

25. Taub, M., and G. Sato. 1980. Growth of functional primary cultures of kidney epithelial cells in defined medium. J. Cell. Physiol. 105:369-378.

26. Deuel, T. F. 1987. Polypeptide growth factors: roles in normal and abnormal cell growth. Annu. Rev. Cell Biol. 3:443-492.

27. Coffey, R. J., Jr., A. S. Goustin, A. M. Soderquist, G. D. Shipley, J. Wolfshohl, G. Carpenter, and H. L. Moses. 1987. Transforming growth factor alpha and beta expression in human colon cancer lines: implications for an autocrine model. Cancer Res. 47:4590-4594.

28. Coffey, R. J., Jr., R. Derynck, J. N. Wilcox, T. S. Bringman, A. S. Goustin H. L. Moses, and M. R. Pittelkow. 1987. Production and auto-induction of transforming growth factor-alpha in human keratinocytes. Nature (Lond.). 328:817820.

29. Malden, L. T., U. Novak, and A. W. Burgess. 1989. Expression of transforming growth factor alpha messenger RNA in the normal and neoplastic gastrointestinal tract. Int. J. Cancer. 43:380-384.

30. Koyama, S., and D. K. Podolsky. 1989. Differential expression of transforming growth factors alpha and beta in rat intestinal epithelial cells. J. Clin. Invest. 83:1768-1773.

31. Beauchamp, R. D., J. A. Barnard, C. M. McCutchen, J. A. Cherner, and R. J. Coffey, Jr. 1989. Localization of transforming growth factor alpha and its receptor in gastric mucosal cells. Implications for a regulatory role in acid secretion and mucosal renewal. J. Clin. Invest. 84:1017-1023.

32. D'Ercole, A. J., A. D. Stiles, and L. E. Underwood. 1984. Tissue concentration of somatomedin-C: further evidence for multiple sites of synthesis and paracrine or autocrine mechanisms of action. Proc. Natl. Acad. Sci. USA. 81:935-939.

33. King, G. L., C. R. Kahn, M. M. Rechler, and S. P. Nissley. 1980. Direct demonstration of separate receptors for growth and metabolic activities of insulin and multiplication-stimulating activity (an insulinlike growth factor) using antibodies to the insulin receptor. J. Clin. Invest. 66:130-140.

34. Vostreks, M., P. L. Moran, and P. A. Seligman. 1988. Transferrin synthesis by small cell lung cancer cells acts as an autocrine regulator of cellular proliferation. J. Clin. Invest. 82:331-339.

35. Trowbridge, I. S., and D. L. Domingo. 1981. Anti-transferrin receptor monoclonal antibody and toxin-antibody conjugates affect growth of human tumour cells. Nature (Lond.). 294:171-173.

36. Ristow, H.-J., and T. O. Messme. 1988. Basic fibroblast growth factor and insulin-like growth factor 1 are strong mitogens for cultured mouse keratinocytes. Cell. Physiol. 137:277-284.

37. Bar, R. S., M. Boes, B. A. Booth, B. L. Dake, S. Henry, and M. Hart. 1989. The effects of platelet-derived growth factor in cultured microvessel endothelial cells. Endocrinology. 124:1841-1848.

38. Lynch, S. E. J. C. Nixon, R. B. Colvin, and H. N. Antoniades. 1987, Role of platelet-derived growth factor in wound healing: synergistic effects with other growth factors. Proc. Natl. Acad. Sci. USA. 84:7696-7700.

39. Larsson, H., E. Carlsson, H. Mattsson, L. Lundell, F. Sundler, G. Sundel, B. Wallmark, T. Watanabe, and R. Hakanson. 1986. Plasma gastrin and gastric enterochromaffinlike cell activation and proliferation. Gastroenterology. 90:391399.

40. Hakanson, R., S. Vallgren, M. Ekelund, J. F. Rehfeld, and F. Sundler. 1984. The vagus exerts trophic control of the stomach in the rat. Gastroenterology. 86:28-32.

41. Lehy, T., and F. Puccio. 1988. Influence of bombesin on gastrointestinal and pancreatic cell growth in adult and suckling animals. In Bombesin-like peptides in health and disease. Y. Tache, P. Melchiorri, L. Negri, editors. NY Acad. Sci. 255-267.

42. Cuttitta, F., D. N. Carney, and J. Mulshine. 1985. Bombesin-like peptides can function as autocrine growth factors in human small-cell lung cancer. Nature (Lond.). 316:823-826. 